\title{
Forest ecosystem services affected by natural disturbances, climate and land-use changes in the Tatra Mountains
}

\author{
Peter Fleischer ${ }^{1,2}$, Viliam Pichler ${ }^{1}$, Peter Fleischer Jr. ${ }^{1}$, Ladislav Holko ${ }^{3}$, \\ František Máliš ${ }^{1,4}$, Erika Gömöryováa, ${ }^{1, *}$, Pavel Cudlín ${ }^{5}$, Jan Holeksa ${ }^{6}$, Zuzana \\ Michalová ${ }^{7}$, Zuzana Homolová ${ }^{2}$, Jaroslav Škvarenina ${ }^{1}$, Katarína Střelcová ${ }^{1}$, \\ Pavol Hlaváč ${ }^{1}$
}

\author{
${ }^{1}$ Faculty of Forestry, Technical University in Zvolen, 96053 Zvolen, Slovakia \\ ${ }^{2}$ Research Station of TANAP, State Forest of TANAP, 05960 Tatranská Lomnica, Slovakia \\ ${ }^{3}$ Institute of Hydrology, Slovak Academy of Sciences, 03105 Liptovský Mikuláš, Slovakia \\ ${ }^{4}$ Forest Research Institute Zvolen, National Forest Centre, 96092 Zvolen, Slovakia \\ ${ }^{5}$ Institute of Systems Biology and Ecology, Academy of Sciences, 37005 České Budejovice, Czech Republic \\ ${ }^{6}$ Faculty of Biology, Adam Mickiewicz University, 61614 Poznań, Poland \\ ${ }^{7}$ Faculty of Forestry and Wood Technology, Czech University of Life Sciences, 16521 Prague, Czech Republic
}

\begin{abstract}
The consequences of large-scale disturbances magnified by climate extremes and land-use changes in Norway spruce forests in the Tatra Mountains (Slovakia) are assessed in this study. The study area is part of the territory of Tatra National Park (TANAP). The driver-pressurestate-impact-response (DPSIR) framework was applied to evaluate how the ecosystem and its services are affected. The state of the ecosystem and its potential for provisioning ecosystem services before and after disturbances is expressed by a set of indicators derived mostly from long-term ecological research conducted in TANAP. The differences are classified by a standardised change index (CI). Ten years after the major windthrow disturbance in 2004, all ecosystem services were still below the pre-disturbance state. The most pronounced declines were found in cultural (average $\mathrm{CI}=0.69$ ) and provisioning (average $\mathrm{CI}=0.86$ ) ecosystem services. Regulating services are recovering faster (average $\mathrm{CI}=0.97$ ), with some indicators exceeding the state before the disturbances. Significant changes took place at the tree line, which is a new phenomenon not known from previous disturbances. Despite a gradual recovery of the ecosystem state and functioning, this analysis confirms that there is a serious risk of decline in forest ecosystem benefits according to regional climate change projections. It also indicates the increasing importance of sustainable forest management for safeguarding ecosystem services under changing conditions.
\end{abstract}

KEY WORDS: Forest ecosystem state $\cdot$ Bark beetle outbreak $\cdot$ Long-term research

\section{INTRODUCTION}

Ecosystem services (ES) are the benefits that people receive from nature, natural processes or ecosystem functions. As such, they reflect societal values, goals, desires and benefits (TEEB 2010, Kelble et al. 2013). ES are generally categorised into provisioning

${ }^{*}$ Corresponding author: gomoryova@tuzvo.sk

${ }^{\S}$ Advance View was available online June 28, 2017
(PES), regulating (RES) and cultural services (CES), as well as ecosystem functions. The capacity of forest ecosystems to provide ES depends on their state (Sing et al. 2015), which can be described by various indicators. PES provide goods (e.g. timber, biomass, water, game, etc.), while RES are the benefits obtained from the regulation of ecosystem processes

() The authors 2017. Open Access under Creative Commons by Attribution Licence. Use, distribution and reproduction are unrestricted. Authors and original publication must be credited. 
(e.g. water regulation and purification, carbon balance, nutrient content, etc.). CES are non-material benefits achieved through cognitive development, reflection, recreation, etc. Ecosystem deterioration by external pressures may reduce both the quantity and quality of expected services.

Forest ecosystem services are threatened by increasing natural disturbances in many parts of the world, particularly in relation to climate change (e.g. Schelhaas et al. 2003, Seidl et al. 2014). At the same time, a higher susceptibility of forests to disturbance has been interpreted as a consequence of past land use (Seidl et al. 2009). However, recent large-scale dieback in remote natural forests, even at the alpine treeline, confirms the complexity and still rather limited knowledge of the interactions among disturbances, climate and land-use changes that seriously affect ecosystem functions and services (Dale 1997, Thom \& Seidl 2016). The emerging conflict between increasing demands and a compromised or limited ES capacity is one of the key challenges for forest management and protection.

Different approaches have been proposed to resolve conflicts between the demands for ES and their provisioning capacity. 'Cause-effect' models are widely used to illustrate the relation among indicators describing pressures and impacts in ecosystems (Smeets \& Weterings 1999). The DPSIR (driverpressure-state-impact-response) framework (Levin et al. 2008) is an example of such a model. It is a conceptual tool for structuring and communicating policy-relevant environmental research, which expresses how human society impacts on ecosystems (EEA 2005). Its application to certain problems helps to identify crucial points in the causal chain of DPSIR and supports decision-making processes to mitigate the negative effects that the driving forces may have. Social and economic developments or natural disturbances (driving forces) exert pressures on the environment and, as a consequence, the state of the environmental changes. This leads to impacts on ecosystems, human health and society, which may elicit a societal response to the driving forces, state or impacts via various mitigation, adaptation or curative actions (Smeets \& Weterings 1999).

The objective of this study was to assess the impacts of key drivers that cause changes in mountain forests and the alpine treeline on ES provisioning in the Tatra Mountains. The study area, protected as a national park, has been heavily affected by repeated natural disturbances, of which the severity has been magnified by climate and land-use changes. We investigated how ES changed 5 and 10 yr after an extraordinary large-scale windthrow disturbance in 2004, the role of changing land use and the possible impacts of changing climate. The analysis was based on an assessment of indicators that were derived from published long-term ecological research and monitoring data (Fleischer 2008). We applied the DPSIR framework to assess the ecosystem state and its capacity to provide ES. To our knowledge, this study represents the first application of this type of analysis in the Tatra Mountains. The results could assist National Park managers in balancing societal requirements with the potential of the forest ecosystems to provide the benefits of nature to people under changing environmental conditions.

\section{MATERIALS AND METHODS}

\subsection{Study site and disturbances}

The Tatra Mountains are the highest part of the Carpathians and are situated along the border between Slovakia and Poland. Although the altitude of many peaks exceeds $2000 \mathrm{~m}$ above sea level (a.s.l.), the mountains cover a relatively small area $\left(341 \mathrm{~km}^{2}\right)$ and the main ridge is only $26 \mathrm{~km}$ long. Despite century-long use by humans for wood and grazing, the forests still cover a large continuous area, covering around $400 \mathrm{~km}^{2}$. An abrupt change in land use occurred in 1949 when the Tatra National Park was established. Various management approaches were applied afterwards with the aim to reconstruct ecosystems disturbed by earlier human overuse and to safeguard an array of ES, such as tourism, recreation, steep slope stabilisation, water regulation, habitat protection and wood production. Since the mid-1990s, a non-intervention approach has been applied on approximately $30 \%$ of TANAP forests, which has had a significant negative effect on traditional land-use (Koreň 2015).

The Tatra Mountains are frequently hit by damaging downslope winds that storm their lee side. During the past $200 \mathrm{yr}$, massive forest destruction caused by such winds occurred in 1834, 1868, 1898, 1915, 1919, 1925, 1941, 1971, 1981, 2004 and 2014 (Koreň 2015, Holeksa et al. 2016). On a regional scale, the windthrow event of 2004 was the most severe known wind disturbance in the history of the Tatra Mountains (Zielonka et al. 2010). The wind gusts exceeded $230 \mathrm{~km} \mathrm{~h}^{-1}$ and laid down some 2.3 million $\mathrm{m}^{3}$ of the forests' standing volume across $120 \mathrm{~km}^{2}$ (30\% of the forest area), making it one of the 10 most devastating storms in Europe in recent decades (Gardiner et al. 
2010). Along with this harmful event, the extraordinarily high summer temperatures recorded after the 2004 disturbance caused forest fires and unprecedented European spruce bark beetle (Ips typographus, hereafter bark beetle) outbreaks. During the last decade, air temperatures have exceeded the long-term climatological mean (1930-1960) for the growing season several times, particularly in 2007, 2012 and 2015 when the temperature was higher than the climatological mean by $1.6,1.5$ and $1.9{ }^{\circ} \mathrm{C}$, respectively. The combination of windthrow disturbance and elevated temperature has resulted in an increase in various pressures that have severely affected the ecosystem and its services. High numbers of fallen trees combined with warm weather lead to an increased risk of bark beetle population outbreak (e.g. Schroeder \& Lindelöw 2002, Wermelinger 2004). Indeed, unlike in the past, a massive bark beetle outbreak spread upslope up to the treeline (1500-1650 $\mathrm{m}$ a.s.l.) and damaged more than $70 \mathrm{~km}^{2}$ of mature, mostly natural, Norway spruce Picea abies (L.) Karst and European larch Larix decidua Mill) forest (Fleischer et al. 2016). Warm weather and dry periods caused forest fires on the scale of several square kilometres.

Although we focus on natural drivers, the recent socioeconomic developments in the study area should also be mentioned. Large investments in winter sport resorts made in the last decade (€200 million) and a $50 \%$ increase in the transport capacity and area of ski slopes have dramatically increased the pressure on supramontane and subalpine forests in the Tatra Mountains, which has particularly affected the treeline.

Five research sites, each 100 ha in size, were established in TANAP in 2006-2008 to assess the response of ecosystems and their functions and services to the wind, fire and bark beetle disturbances as well as to different land-use practices, with different types of human intervention. The EXT and FIR sites represent salvage-logged windthrow and windthrow burnt by incidental fire, respectively. The sites without human intervention are NEX (no timber extraction) and IPS (site with no timber extraction disturbed by bark beetle). The REF site represents intact reference conditions. For a detailed description see Fleischer (2008).

\subsection{DPSIR model, ecosystem services and indicators}

We applied the DPSIR framework to evaluate the impacts of disturbance (windthrow, fire, bark beetle), land use (natural unmanaged forest, semi-natural managed forest) and climate (increasing temperature) on ES. To apply the DPSIR framework, we adhered to the generally applicable criteria for discerning drivers, pressures, states and impacts as established by Oesterwind et al. (2016). Fig. 1 illus-

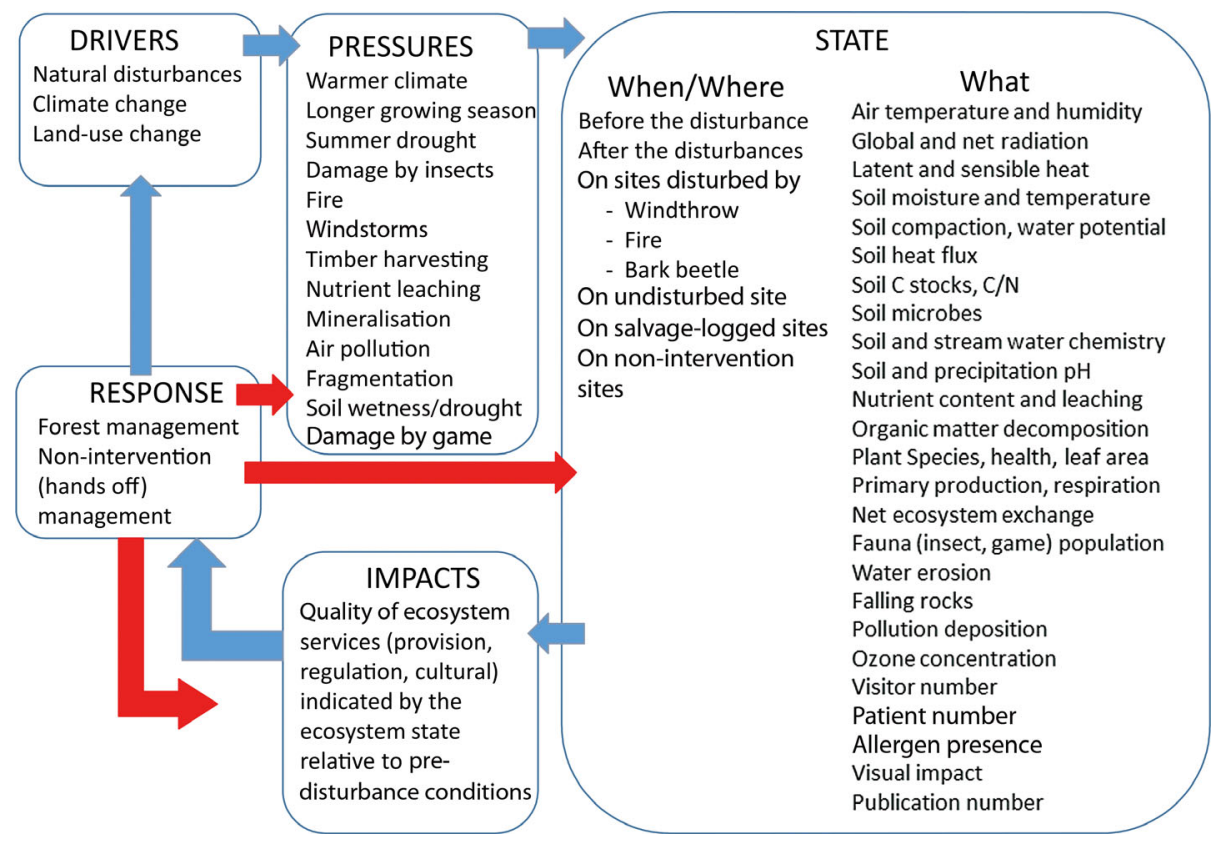

Fig. 1. Conceptual model for evaluation of forest ecosystem services in the Tatra Mountains using the driver-pressure-stateimpact-response (DPSIR) approach (blue arrows) and possible societal response (red arrows) 
trates the concept of progressive environmental changes induced by the driving forces, i.e. natural disturbances, climate and land-use changes, and their impacts on ES.

We understand pressures as processes (air and water warming, mineralisation, leaching, fragmenta- tion, insect outbreaks, drought, erosion, etc.) stimulated by the drivers. The magnitude of the pressures determines the state and the functioning of an ecosystem. The state of an ecosystem is its capacity for providing ES on a certain level that we interpret as impact. The state evaluated in time intervals is cru-

Table 1. List of ecosystem state indicators categorised according to the ecosystem services (PES, provisioning; RES, regulating; CES, cultural) and their relative normalized change index (CI), when compared with the reference (REF) value (pre-disturbance state recorded at the REF site in 2004 [REF0] or alternatively, a site-specific value if recorded at the distinct research site before the disturbance) according to land-use types (EXT: salvage-logged windthrow; FIR: windthrow burnt by incidental fire; NEX: no timber extraction; IPS: no timer extraction but disturbed by bark beetle occurrence including treeline) and the time of assessment ( 5 and $10 \mathrm{yr}$ after the disturbance). +/- indicates the interpretation of increasing ecosystem state indicator value on ecosystem functioning and ES provision based on the authors' evaluation. See Section 2.2 for further details. Key indicators are in bold

\begin{tabular}{|c|c|c|c|c|c|c|c|c|}
\hline $\begin{array}{l}\text { Ecosystem } \\
\text { service } \\
\text { category }\end{array}$ & Indicator (unit) & $\begin{array}{l}\text { ES trend } \\
(+/-)\end{array}$ & $\begin{array}{c}\text { REF } \\
\text { REF0 } \\
\text { or site } \\
\text { value }\end{array}$ & REF 5 & REF 10 & $\begin{array}{l}-\mathrm{CI}_{i j} \\
\operatorname{EXT} 5\end{array}$ & EXT 10 & FIR 5 \\
\hline \multirow{12}{*}{ PES } & Gross primary production $\left(\mathrm{g} \mathrm{C} \mathrm{m}^{-2}\right)$ & + & 1282 & 0.92 & 0.85 & 0.43 & 0.93 & 0.96 \\
\hline & Leaf area index $\left(\mathrm{m}^{2} \mathrm{~m}^{-2}\right)$ & + & 6 & 0.92 & 0.67 & 0.2 & 0.63 & 0.33 \\
\hline & Net primary production $\left(\mathrm{g} \mathrm{C} \mathrm{m}^{-2}\right)$ & + & $460-505$ & 0.81 & 0.18 & 0.63 & 0.62 & 0.83 \\
\hline & Natural regeneration (ind. ha $^{-1}$ ) & + & 2200 & 1.09 & 1.18 & 2.04 & 1.63 & 2.00 \\
\hline & Dead wood $\left(\mathrm{m}^{3} \mathrm{ha}^{-1}\right)$ & + & 77 & 1.09 & 1.17 & 1.43 & 1.43 & 0.39 \\
\hline & Fragmentation (\%) & - & 15 & 0.88 & 0.75 & 0.16 & 0.16 & 0.16 \\
\hline & Yield $\left(\mathrm{m}^{3} \mathrm{ha}^{-1}\right)$ & + & 280 & 1.04 & 0.25 & 0.00 & 0.04 & 0.00 \\
\hline & Soil fauna diversity (n) & + & 5 & 1.00 & 0.60 & 2.80 & 1.00 & 3.20 \\
\hline & Game $\left(\mathrm{n} \mathrm{ha}^{-1}\right)$ & - & 0.5 & 1.00 & 1.00 & 0.50 & 0.33 & 0.50 \\
\hline & Bark beetle population ( $\%$ trees infested) & - & 30 & 0.75 & 0.60 & 1.00 & 1.00 & 1.00 \\
\hline & Tree species (n) & + & 2 & 1.00 & 1.00 & 2.00 & 2.50 & 2.50 \\
\hline & Plant species (n) & + & 22 & 1.09 & 1.05 & 0.36 & 0.77 & 0.32 \\
\hline \multirow[t]{28}{*}{ RES } & Respiration ( $\mathrm{g} \mathrm{C} \mathrm{m}^{-2}$ ) & - & 1235 & 1.07 & 1.16 & 1.15 & 0.93 & 0.96 \\
\hline & C balance $\left(\mathrm{g} \mathrm{C} \mathrm{m}^{-2}\right)$ & + & 47 & 0.74 & 0.40 & 0.16 & 0.21 & 0.22 \\
\hline & Total organic $\mathrm{C}\left(\mathrm{mg} \mathrm{l}^{-1}\right)$ & - & 375 & 0.99 & 0.99 & 0.99 & 0.99 & 1.00 \\
\hline & $\mathrm{C} / \mathrm{N}$ & - & 22 & $0, .6$ & 0.96 & 1.00 & 1.05 & 1.31 \\
\hline & $\mathrm{C}$ stock $\left(\mathrm{Mg} \mathrm{C} \mathrm{ha}{ }^{-1}\right)$ & + & 92 & 1.09 & 1.12 & 1.02 & 0.94 & 0.94 \\
\hline & Leaching (index) & - & 4.6 & 1.00 & 0.92 & 0.58 & 0.92 & 0.55 \\
\hline & Soil $\mathrm{pH}$ & + & $3.9-4.8$ & 1.00 & 1.00 & 0.98 & 0.98 & 0.98 \\
\hline & Microbial diversity & + & 226 & 0.39 & 0.51 & 0.33 & 0.56 & 0.30 \\
\hline & Cellulose decomposition (\%) & + & 25 & 1.00 & 1.00 & 1.60 & 1.60 & 2.40 \\
\hline & Naturalness (\% of natural stands) & + & $20-90$ & 1.00 & 1.00 & 0.25 & 0.40 & 0.25 \\
\hline & High flow pulses (n) & - & 90 & 0.75 & 0.69 & 0.82 & 0.69 & 0.64 \\
\hline & Flow reversals (n) & - & 7 & 1.00 & 1.00 & 1.00 & 1.00 & 0.46 \\
\hline & Flow minimum (index) & - & $0.15-0.4$ & 0.33 & 0.33 & 0.87 & 1.00 & 0.60 \\
\hline & Interception ( $\%$ of rain retained by canopy & py) + & 42 & 0.90 & 0.67 & 0.24 & 0.24 & 0.12 \\
\hline & Ground water level (m) & - & 2.5 & 0.40 & 0.58 & 0.40 & 0.58 & 0.40 \\
\hline & Surface runoff $(\%)$ & - & $0.61-1.57$ & 0.87 & 0.76 & 0.32 & 0.41 & 0.27 \\
\hline & Erosion $\left(\mathrm{kg} \mathrm{ha}^{-1} \mathrm{yr}^{-1}\right)$ & - & 0.007 & 0.43 & 0.43 & 0.70 & 1.00 & 0.70 \\
\hline & $\mathrm{O}_{3}(\mathrm{ppb})$ & - & $39-48$ & 1.08 & 1.05 & 1.08 & 1.05 & 1.08 \\
\hline & Precipitation $\mathrm{pH}$ & + & $4.0-4.1$ & 1.07 & 1.36 & 1.20 & 1.38 & 1.05 \\
\hline & Soil temperature $\left({ }^{\circ} \mathrm{C}\right)$ & - & $7.4-9.0$ & 0.98 & 0.78 & 0.72 & 0.82 & 0.80 \\
\hline & Air temperature $\left({ }^{\circ} \mathrm{C}\right)$ & - & $11.0-11.5$ & 0.94 & 0.92 & 0.85 & 0.84 & 0.86 \\
\hline & Soil moisture (\%) & + & $33-38$ & 1.00 & 1.08 & 0.86 & 0.70 & 1.06 \\
\hline & Snow accumulation (cm) & + & $150-250$ & 1.00 & 1.10 & 1.00 & 1.08 & 1.00 \\
\hline & Sensible heat ( $\%$ in energy balance) & - & 45.9 & 0.96 & 0.92 & 0.83 & 0.84 & 0.79 \\
\hline & Wind velocity $\left(\mathrm{m} \mathrm{s}^{-1}\right)$ & - & 0.2 & 0.67 & 0.50 & 1.06 & 1.2 & 1.11 \\
\hline & Fire risk (index) & - & 1 & 1.00 & 0.50 & 0.14 & 0.25 & 0.33 \\
\hline & Rockfall risk (index) & - & 1 & 1.00 & 1.00 & 1.00 & 1.00 & 1.00 \\
\hline & Treefall risk (index) & - & 1 & 0.50 & 0.33 & 1.00 & 1.00 & 1.00 \\
\hline \multirow[t]{4}{*}{ CES } & Visitors (n) & + & 18000 & 0.88 & 1.17 & 0.88 & 1.17 & 0.88 \\
\hline & Patients (n in climatic spa) & + & 3000 & 0.63 & 0.40 & 0.63 & 0.40 & 0.63 \\
\hline & Attractiveness (index) & + & 1 & 1.00 & 0.80 & 0.50 & 0.55 & 0.50 \\
\hline & Allergen, disease (index) & - & 1 & 0.66 & 0.50 & 0.28 & 0.25 & 0.67 \\
\hline
\end{tabular}


cial for the detection of changes in state, in our case before and after ( 5 and $10 \mathrm{yr}$ after the windthrow disturbance in 2004). The ecosystem state before the disturbance was used to classify ES modified by different disturbance and land-use types. The impact on PES, RES and CES was analysed.

The identification and description of the ecosystem changes was based on the indicators published by scientists involved in 'windstorm research' (Fleischer 2008). The indicators presented in this study (Table 1) are physical, chemical and biological variables that describe the current status of drivers, pressures and impacts on the studied ecosystem. We summarised all published data, derived indicators and assigned them to the DPSIR categories. A total of 44 indicators were selected, which were grouped into 3 categories characterising PES (12 indicators), RES (28 indicators) and CES (4 indicators) (Table 1). Then, we classified the indicators by increasing or decreasing tendency (before the disturbance, 5 and $10 \mathrm{yr}$ after) using the change index (CI). Indicators at all the sites were standardised with the reference values, applying the rule 'the higher the better' (Wang et al. 2015). We chose 2004 and the REF site as the reference for

$\begin{array}{llllll} & & & & & \\ \text { FIR } 10 & \text { NEX } 5 & \text { NEX } 10 & \text { IPS } 5 & \text { IPS } 10 & \end{array}$

\begin{tabular}{|c|c|c|c|c|c|}
\hline 0.92 & 0.95 & 1.11 & 0.63 & 0.39 & Fleischer (2016) \\
\hline 0.73 & 0.35 & 0.73 & 0.50 & 0.28 & Fleischer (2016) \\
\hline 0.81 & 0.76 & 0.90 & 0.13 & 0.28 & Kyselová \& Homolová (2012), Pajtík et al. (2015), Fleischer (2016) \\
\hline 2.51 & 3.63 & 3.77 & 1.33 & 2.13 & Jonášová et al. (2010), Šebeň et al. (2011b), Michalová (2015) \\
\hline 0.39 & 3.25 & 3.38 & 3.25 & 3.38 & Šebeň et al. (2011a) \\
\hline 0.16 & 0.13 & 0.11 & 0.30 & 0.18 & Kopecká \& Nováček (2009), Havašová et al. (2017) \\
\hline 0.04 & 0.01 & 0.04 & 0.50 & 0.11 & State Forests of TANAP, Tutka (2009) \\
\hline 1.00 & 1.00 & 0.40 & 0.75 & 0.75 & Hloška et al. (2016) \\
\hline 0.33 & 0.50 & 0.50 & 0.50 & 0.25 & State Forests of TANAP \\
\hline 1.00 & 0.86 & 0.75 & 0.50 & 0.40 & Nikolov et al. (2014) \\
\hline 3.50 & 0.50 & 0.50 & 1.00 & 1.00 & Šebeň et al. (2011b), Fleischer (2016) \\
\hline 0.54 & 0.63 & 1.00 & 1.12 & 1.31 & Máliš et al. (2015) \\
\hline 0.97 & 0.98 & 0.88 & 0.73 & 0.78 & Fleischer (2016) \\
\hline 0.25 & 0.45 & 0.49 & 0.06 & 0.04 & Fleischer (2016) \\
\hline 1.00 & 1.00 & 1.00 & 1.00 & 1.00 & Ziegler (2007), Frič \& Škvarenina (2008) \\
\hline 1.29 & 1.16 & 1.10 & 1.00 & 1.05 & Don et al. (2012), Hanajík \& Šimonovičová (2015), Gömöryová et al. (2017) \\
\hline 0.96 & 1.00 & 0.98 & 1.00 & 0.97 & Don et al. (2012), (2015) \\
\hline 0.90 & 0.55 & 0.94 & 0.84 & 0.82 & Bischoff et al. (2008), Fleischer (2014) \\
\hline 1.00 & 1.13 & 1.08 & 1.00 & 1.00 & Šimkovič et al. (2009), Gömöryová et al. (2017) \\
\hline 0.52 & 0.74 & 0.81 & 0.39 & 0.40 & Gömöryová et al. (2017) \\
\hline 1.60 & 2.60 & 1.60 & 1.25 & 1.40 & Kyselová \& Homolová (2011), Z. Kyselová (pers. comm.) \\
\hline 0.75 & 1.29 & 1.29 & 1.00 & 1.00 & www.lesytanap.sk \\
\hline 0.56 & 0.64 & 0.56 & 0.64 & 0.56 & Holko et al. (2012), Holko \& Škoda (2016) \\
\hline 0.35 & 0.46 & 0.35 & 0.46 & 0.46 & Holko et al. (2012), Holko \& Škoda (2016) \\
\hline 0.25 & 0.70 & 0.25 & 0.70 & 0.40 & Holko et al. (2012), Holko \& Škoda (2016) \\
\hline 0.36 & 0.52 & 0.66 & 0.53 & 0.36 & Fleischer (2014) \\
\hline 0.58 & 0.40 & 0.58 & 0.40 & 0.58 & Bičárová (2011), S. Bičárová (pers. comm.) \\
\hline 0.34 & 0.76 & 0.87 & 0.89 & 0.89 & Sitko et al. (2011) \\
\hline 1.00 & 0.70 & 1.00 & 0.70 & 0.09 & Sitko et al. (2011) \\
\hline 1.05 & 1.05 & 1.08 & 1.06 & 1.17 & Bičárová et al. (2015) \\
\hline 1.34 & 1.13 & 1.35 & 1.12 & 1.35 & Fleischer (2014) \\
\hline 0.89 & 0.92 & 0.88 & 0.93 & 0.88 & Fleischer (2014), Fleischer (2016) \\
\hline 0.84 & 0.85 & 0.83 & 0.85 & 0.79 & Matejka \& Fleischer (2011), Fleischer (2014) \\
\hline 1.09 & 1.02 & 0.95 & 1.11 & 1.05 & Fleischer (2016), \\
\hline 1.08 & 1.00 & 1.07 & 1.00 & 1.00 & Bartík et al. (2014) \\
\hline 1.56 & 0.75 & 3.85 & 0.88 & 0.81 & Fleischer et al. (2012), Fleischer (2014) \\
\hline 1.25 & 1.06 & 1.13 & 0.28 & 0.15 & P. Fleischer (unpubl.) \\
\hline 0.33 & 0.10 & 0.25 & 0.14 & 0.11 & www.lesytanap.sk \\
\hline 1.00 & 1.00 & 1.00 & 0.25 & 0.25 & www.lesytanap.sk \\
\hline 1.00 & 0.50 & 0.50 & 0.14 & 0.11 & Kajba et al. (2013), www.lesytanap.sk \\
\hline 1.17 & 0.88 & 1.17 & 0.88 & 1.17 & www.lesytanap.sk \\
\hline 0.40 & 0.63 & 0.40 & 0.63 & 0.40 & Božíková (2009), J. Božíková (pers. comm.) \\
\hline 0.55 & 0.50 & 0.55 & 0.50 & 0.50 & Vyskot et al. (2007), Čekovská (2013) \\
\hline 0.25 & 0.66 & 0.33 & 0.50 & 0.50 & Turčeková et al. (2014), Homolová et al. (2015) \\
\hline
\end{tabular}


this analysis (hereafter REF0). In a limited number of cases (where available), pre-disturbance values at disturbed sites were used as a reference. Two types of formula were applied to standardise the indicator values, reflecting their different temporal dynamics (increasing, decreasing) and impact (positive, negative) on the ES:

$$
\begin{aligned}
\mathrm{CI}_{i j} & =\frac{\mathrm{REF} 0}{\boldsymbol{X}_{i j}}(\text { increasing value increases ES }) \\
\mathrm{CI}_{i j} & =\frac{\boldsymbol{x}_{i j}}{\mathrm{REF} 0}(\text { increasing value decreases ES })
\end{aligned}
$$

where $x_{i j}$ is the state indicator real value, $i$ is disturbance and land-use type (EXT, FIR, NEX, IPS, REF) and $j$ is temporal category (5 and $10 \mathrm{yr}$ after the disturbance).

CI value $<1$ indicated a decline and values $>1$ indicated an increase in ES compared with pre-disturbance conditions. The average CI value was calculated for each ES category from all the indicators. The development trajectories (differences among the study sites) were evaluated using principal component analysis (PCA). A descriptive classification of the indicator change (positive or negative) on the ES was based on a literature review (Thom \& Seidl 2016) and the authors' interpretation (Table 1).

The relevance of the indicators for the ES was assessed post priori. The key indicators were identified in 2 steps. First, using exploratory factor analysis (EFA; R Development Core Team 2008), the groups of indicators were identified following the approach outlined by Bryce et al. (2016). Alternatively, in cases where the statistical interpretation was uncertain, we applied an expert estimation approach (GrêtRegamey et al. 2015). Second, the most relevant indicators were selected by correlation analysis. The indicator with the highest correlation to other indicators inside the statistically or intentionally derived groups was denoted as the key indicator. cades, increasing air temperature has been recorded at meteorological stations located in the vicinity of the Tatra Mountains. As an example, Fig. 2 shows data from Tatranská Lomnica (elevation 830 m a.s.l.), where measurements started in 1898. The largest windthrow disturbances in the Tatra Mountains during the last $100 \mathrm{yr}$ were plotted against the backdrop of the annual average temperature and indicate that the most recent windthrow disturbances (2004 and 2014) coincided with extremely high air temperatures. This synergy of drivers has a large impact on the forest in the Tatra Mountains. As shown later, higher temperatures resulted in a larger bark beetle population, increased fire risk, etc.

Key results regarding the positive or negative values of ecosystem state indicators are presented in Table 1. A visual interpretation of the ES before and after the disturbances is given in Fig. 3. ES was calculated for each ES category (PES, RES and CES) as an average of all the indicators. Distinct groups of indicators resulted from the application of the statistical EFA and were supplemented by the expert knowledge method. In both cases, a correlation analysis identified the most representative indicators (Table 1). A more detailed description of the ES indicators is elaborated below.

\subsection{PES}

Timber yield after disturbances declined to almost zero and the value of timber losses reached $€ 18$ million (Tutka 2009). Gross primary production (GPP) was initially strongly reduced by the wind disturbances (50\% reduction), but the recovery in recent years has been very fast. Ten years after the disturbances, the GPP for some land-use types (FIR, NEX) reached or even exceeded the pre-disturbance state (Fleischer 2016). Increasing GPP was closely related to the increase in the vegetation cover indicated by

\section{RESULTS}

Repeated disturbances, climate and land-use changes have had a significant impact on the state of the forest ecosystem and its functioning in the study area. Large windthrow events (in 2004 and 2014) and consequent bark beetle outbreaks damaged 200 $\mathrm{km}^{2}$ of the forest during the study period, which represents half of the TANAP forest area. In recent de-

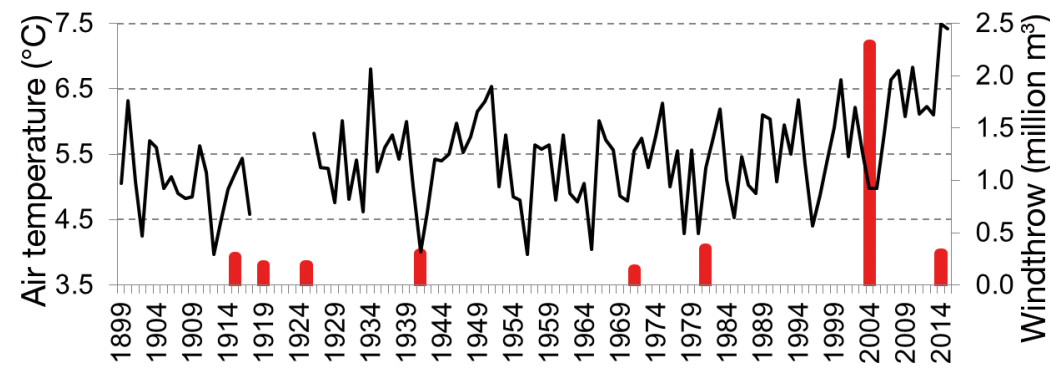

Fig. 2. Mean annual air temperature (Tatranská Lomnica, elevation $830 \mathrm{~m}$ a.s.l., period 1898-2015) and windstorm damage (million $\mathrm{m}^{3}$ of fallen trees). Source: State Forests of TANAP and the Slovak Hydrometeorological Institute 


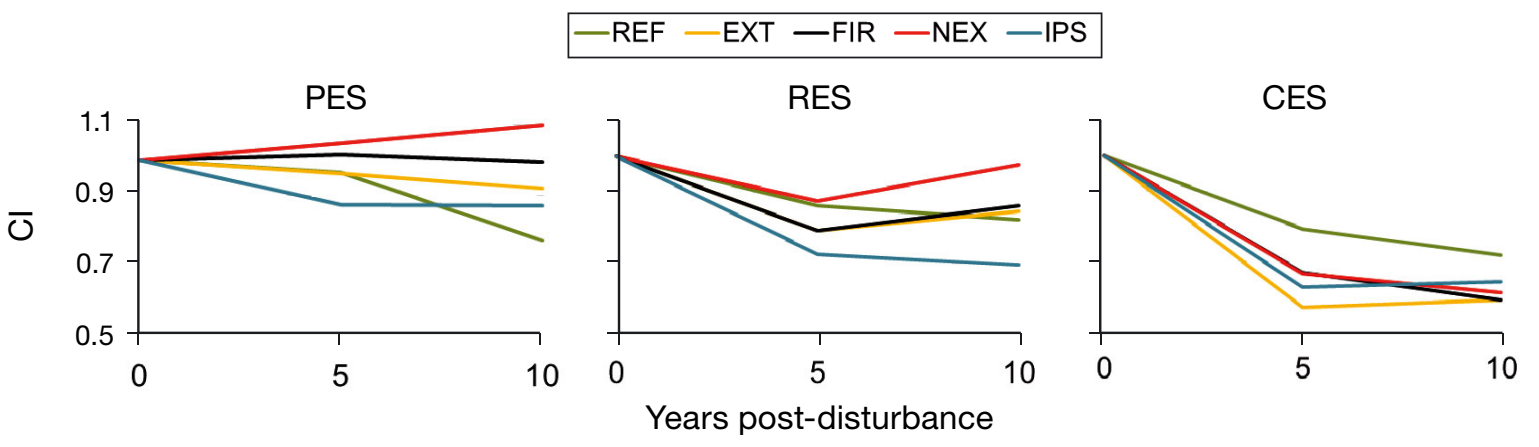

Fig. 3. Trajectories of provisioning (PES), regulating (RES) and cultural (CES) ecosystem services before the disturbance (0) and 5 and $10 \mathrm{yr}$ after the disturbance at sites with different disturbance and land-use practices: REF: reference; EXT:extracted windthrow; FIR: burnt extracted windthrow; NEX: non-extracted windthrow; IPS: non-extracted site disturbed by bark beetle. Temporal values represent the average normalised change index (CI) of ecosystem service provision indicators ( $\mathrm{n}=12 \mathrm{for}$ PES, $\mathrm{n}=28$ for RES and $\mathrm{n}=4$ for CES)

the leaf area index (LAI; Fleischer et al. 2015, Fleischer 2016). A different situation occurred at the treeline, which was disturbed by bark beetle occurrence. The current GPP is $39 \%$ of the pre-disturbance value and the vegetation cover features sparse successional vegetation in formerly closed canopy stands.

The ground vegetation biomass increased after the windthrow disturbance at all sites. The aboveground biomass was almost identical on both salvage-logged and non-intervention windthrow sites $\left(9300 \mathrm{~kg} \mathrm{ha}{ }^{-1}\right)$. The annual biomass stocks culminated 5-7 yr after the disturbance, with the highest value observed on the burnt windthrow (FIR) site (Kyselová \& Homolová 2012). In the following years, the biomass declined, mostly in the salvage-logged sites (Fleischer 2016). The decline resulted in a slight reduction of PES. Both grass and herb species assemblages did not differ considerably but the salvage logging in the EXT site favoured colonisation rate and an increase in the abundance of early successional tree species. The differences in the natural regeneration of Norway spruce ranged from a few more up to 6 -fold more trees per study site in favour of the non-intervention sites compared with the salvage-logged site during early post-disturbance years. In more recent years, the difference has begun to disappear due to factors such as competition from the surrounding vegetation (e.g. Jonášová et al. 2010, Šebeň et al. 2011b, Máliš et al. 2015, Michalová 2015). Jonášová et al. (2010) mentioned mechanical destruction during logging as responsible for a poorer regeneration of Norway spruce in EXT. At the same time, the salvage-logged sites EXT and FIR have accommodated a considerably larger number of pioneer broadleaved species, i.e. birch, willow and rowan. Due to reforestation in sites with intervention (EXT, FIR), the number of so-called climax species has been much higher than in both reference (REF) and non-intervention (NEX) sites. Nonetheless, Norway spruce remains the dominant tree species for both land-use types (Fleischer 2016).

With respect to dead wood, Šeben et al. (2011a) found $346 \pm 75 \mathrm{~m}^{3} \mathrm{ha}^{-1}$ of dead wood in the NEX site. In the managed EXT site, the amount was $86 \pm 12 \mathrm{~m}^{3}$ $\mathrm{ha}^{-1}$. Necromass in the undisturbed forest with traditional management was $49 \pm 4 \mathrm{~m}^{3} \mathrm{ha}^{-1}$. The amount of dead wood increased in the IPS site where no pest control measures were applied. In this context, the European spruce bark beetle Ips typographus is the most important insect that affects the forests in the Tatra Mountains. During the first 2 yr after the windthrow disturbance, its population developed in fallen trees with no outward impact. The largest area was disturbed during the following $2 \mathrm{yr}$ and hit even the treeline (Økland et al. 2016). It should be noted that according to Nikolov et al. (2014), unmanaged sites in nature reserves (roughly $400 \mathrm{ha}$ ) were a source of an enormous increase in the bark beetle population. Overall, more than $70 \mathrm{~km}^{2}$ of mature Norway spruce stands were destroyed by the bark beetle (www.lesytanap.sk, Nikolov et al. 2014). Surprisingly, natural bark beetle enemies (e.g. Thanasimus formicarius, Scoloposcelis pulchela, Medetera signaticornis) were unable to exert any control function (Gubka et al. 2010).

PES were substantially reduced by forest fragmentation. The length of forest edges immediately after the windfall of 2004 remained almost the same as in the pre-disturbance state (Kopecká \& Nováček 2009). However, considerable forest fragmentation emerged later due to bark beetle outbreaks (Hlásny et al. 2010), reducing PES mostly at the IPS site.

Water availability, water balance and drinking water quality were included in RES, but might be partly con- 
sidered as PES. Since these indicators remained almost unchanged (Holko et al. 2009, 2012, Holko \& Škoda 2016), water-related PES remained stable. Streams flowing through the windthrow areas showed a higher content of nitrogen compounds for 2-3 yr after the disturbance (Fleischer \& Homolová 2011).

Average CI values in PES after 5 and 10 yr slightly decreased from 0.97 to 0.93 (Fig. 3). A larger decline was observed in salvage-logged (EXT, FIR) than in non-intervention sites (NEX, IPS). The largest difference $(\mathrm{CI}=0.75)$ was documented at REF $10 \mathrm{yr}$ after the disturbance, which nevertheless was caused by another windthrow event that occurred in May 2014.

\subsection{RES}

Generally, RES declined after the disturbances more profoundly than PES. The average CI values were 0.81 and $0.84,5$ and $10 \mathrm{yr}$ after the disturbance, respectively (Fig. 3). In the first 5-yr period, the average $\mathrm{CI}$ declined in all the study sites. In the second period, the decline continued at the IPS and REF sites. The largest declines were observed in carbon sequestration, natural structure, interception, surface runoff and fire risk (Table 1). Less evident declines were observed in parameters describing soil water quality, such as total organic carbon and nitrogen content (Ziegler 2007, Bischoff et al. 2008, Frič \& Škvarenina 2008, Fleischer \& Homolová 2011). Soil physical properties (Fleischer \& Koreň 2009, Hanajík \& Šimonovičová 2015) remained almost unchanged. Stable soil prevented an increase in overland flow generation, soil moisture changes and erosion (Šimkovič et al. 2009, Novák \& Šurda 2010). These processes are generally expected as a consequence of dramatic change in interception and transpiration after canopy destruction (Kn̆ava et al. 2007, Fleischer 2014). Although the surface runoff and particle transport increased several-fold on salvage-logged sites (EXT, REF), the magnitude of erosion was still classified as negligible $\left(<0.7 \mathrm{~kg} \mathrm{ha}^{-1} \mathrm{yr}^{-1}\right)$ for all the disturbance and land-use types (Sitko et al. 2011). Rojan (2015) found pronounced erosion on forest roads used for timber transport, but the area affected was only a few hectares and the recovery was very fast. Water balance, runoff and retention were primarily controlled by precipitation regime and soil-geology properties that were not affected by the disturbance type and subsequent land-use practices (Kn̆ava et al. 2007, Holko et al. 2009, 2012, Novák \& Kňava 2009, Novák \& Šurda 2010, Bičárová \& Holko 2013, Bartík et al. 2014).
Some RES indicators were significantly affected by air temperature. An increase in air temperature caused by the windthrow disturbance was recorded at all the sites. The average air temperature during the growing season increased by $2{ }^{\circ} \mathrm{C}$ in all disturbed sites compared with the intact forest in the first $5 \mathrm{yr}$ (Fleischer et al. 2012). The increased air and soil temperature in salvage-logged sites shortly after the disturbance induced heat stress and a large mortality of young trees (Mišíková \& Škvarenina 2009). Extracted and mostly burnt sites (EXT, FIR) suffered from increased sensible heat flux in early stages after the disturbances (Matejka \& Fleischer 2011). Soil moisture, a very variable indicator (Novák \& Šurda 2010), was more sensitive to the type of land-use practice (bare soil in extracted sites) in the early stage of succession. A few years later, the new vegetation cover eliminated earlier extremes and differences (Fleischer \& Koreň 2009). The difference in the air temperature during the growing season between REF and disturbed sites declined to $1.5^{\circ} \mathrm{C}$ after $10 \mathrm{yr}$. Warmer soil stimulated more intensive soil respiration, which reduced RES. We found temporarily increased soil respiration in the salvage-logged sites, and a surprisingly large soil $\mathrm{CO}_{2}$ efflux was measured close to the treeline. Canopy destruction caused by the bark beetle outbreak increased soil temperature mostly on steep, south-facing slopes. Such a change stimulated mineralisation of the thick soil organic layer and a large $\mathrm{CO}_{2}$ efflux.

Excepting the effects of increased air temperature caused by the forest destruction, meteorological conditions also had a significant influence on ES. In 2015, the mean growing-season (May-August) air temperature above the treeline exceeded the longterm reference normal (1930-1960) by $2.0^{\circ} \mathrm{C}$. Such a temperature increase has been projected by regional climate change models for the time horizon 20502070 (Melo et al. 2013). Two, instead of the usual one, bark beetle Ips typographus generations developed in standing forest as a result of the high air temperature. Three generations developed in fallen trees with eliminated transpiration, which increased pressure on the remaining stands (Fleischer et al. 2016). Dead, frequently falling trees pose a high risk for tourists (Kajba et al. 2013) and preventive measures require large investments. The tree dieback has also increased the risk of falling rocks, mostly at the treeline damaged by bark beetle, which has strongly reduced RES. Warmer weather is correlated with fire risk in the Tatra region (Brunette et al. 2015) and thus reduced RES. Fire risk also significantly increased due to the large amounts of fuelwood that was mostly 
available in stands without salvage logging (NEX, IPS). Forestry evidence (www.lesytanap.sk) showed that more than 40 fires have occurred in the windthrow sites since 2005. Open, disturbed sites have boosted the spread of different plant and animal diseases (Turčeková et al. 2014), which was also interpreted as a decline of RES.

In contrast, the increased temperature positively stimulated the activity of soil microorganisms (Don et al. 2012), even though the differences in microorganism communities related to disturbance and land-use categories have remained rather limited even on ecologically contrasting sites (Gömöryová et al. 2008, 2011). The increased abundance of microorganisms, fungi (Hanajík \& Šimonovičová 2015) and vegetation growth indicate the recovery of the ecosystem and related ES. High temperature and sufficient precipitation in recent years supported carbon sequestration. The disturbances immediately turned all the affected sites into large carbon sources. Ten years after the disturbance, the carbon balance was still slightly negative. The only case with a narrow positive balance was identified at the non-intervention site (NEX). This is a result of the highest LAI and a high proportion of naturally regenerated Norway spruce (Fleischer 2016).

Decline of the dangerous tropospheric ozone $\left(\mathrm{O}_{3}\right)$ concentration after the disturbances was observed. The previously high $\mathrm{O}_{3}$ concentration above the treeline was understood to be one of the most important pressures on forest health (Bičárová \& Fleischer 2006). The destruction of the forest reduced the natural precursors (volatile organic compounds) for ozone formation (Bičárová et al. 2015) produced by the conifers. Similarly, the reduced canopy led to a reduction of precipitation water dripping and stemflow, which would otherwise have channelled pollution deposition into the soil (Fleischer 2014).

\subsection{CES}

CES declined (Fig. 3) 5 yr after the disturbances to $\mathrm{CI}=0.67$ and this tendency continued $(\mathrm{CI}=0.63$ after 10 yr). In terms of CES, Božíková (2009) reported a decline in the clientele of the local climatic spas after the windstorm of 2004. Currently, allergens from grasses, birch and poplar are abundant in all sites. According to Vyskot et al. (2007), recreational and health-related forest CES have been reduced by $35-37 \%$ due to forest destruction. Čekovská (2013) interviewed visitors $(n=138)$ and concluded that the images of vast wind forest destruction lowered the aesthetic appeal and thus also the recreational value of the area as perceived by the public. An increasing number of visitors passing the treeline induced a higher risk of injury through falling trees in the bark beetle-affected areas (Kajba et al. 2013). Most of the above indicators were below the pre-disturbance state and thus indicate the decline of CES provision. Education is one of the few indicators that has increased as the disturbance events have become an important source of information for research, education, practical forestry and nature conservation (Fleischer 2014, Pichler 2015).

PCA analysis revealed a temporal post-disturbance increase of disparity across the 5 study sites (Fig. 4). Before the disturbance in 2004, the environmental conditions at all sites were very similar, as indicated by small distances among the indicator values. The differences increased during the first $5 \mathrm{yr}$ after the disturbances. In the following period (5-10 yr), the differences notably declined, especially among differently managed windthrow sites (EXT, NEX) and different disturbance factors (wind at EXT and fire at FIR). The development at the IPS site (damaged by bark beetle and unmanaged) was notably different; it documented a very sensitive response of the ecosystem at the tree line.

\section{DISCUSSION}

The DPSIR framework is usually presented as a linear chain or a circle with limited capability for indepth analyses and is sometimes considered inappropriate as an analytical tool (Maxim et al. 2009). However, there are also positive examples that the DPSIR framework can reflect the complexity of many interacting factors, some of which may represent

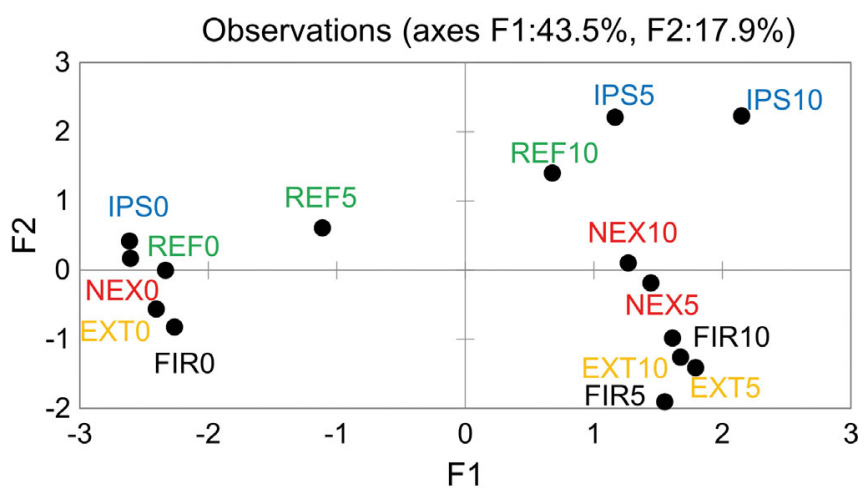

Fig. 4. Principal component analysis based on 44 ecosystem state indicators depicting temporal changes and differences among the study sites with different disturbance and land-use practices. See Fig. 3 for abbreviations and details 
highly nonlinear dynamics (EEA 2005, Niemeijer \& de Groot 2008, Wolfslehner \& Vacik 2008).

The relevance of indicators used in the DPSIR frameworks for the whole system functioning is often expressed by its weight (Wolfslehner \& Vacik 2008). We intentionally gave the same weight to each indicator to avoid a subjective judgement. The approach chosen has some limitations, e.g. occurrence of redundant information, which can bias the interpretation of ES calculated as an average from all indicators. Statistical selection of relevant key indicators often yielded sets with difficult or even unrealistic interpretations. When selecting the key ES indicators, we also considered local expert knowledge available at the Tatra National Park Research Station. Contrary to the key indicators selected by EFA, an expert estimation provided less correlated but more realistic relations. Such an approach based on the local expert knowledge was shown to reduce uncertainties in the estimation of future ES in the Alpine environment (GrêtRegamey et al. 2015). Among the most informative indicators are those used for forest ES mapping in Europe e.g. risk protection, biomass production, carbon sequestration, habitat provision, recreation, etc. (Barredo et al. 2015), or for sustainable forest management e.g. growth and harvest, browsing, natural regeneration, tree species composition, woody debris, biodiversity loss, etc. (Wolfslehner \& Vacik 2008). These indicators are more ES-specific and thus more suitable for further assessment, reporting and comparison of the ES status in the Tatra Mountains.

The concept offers an opportunity to affiliate desirable or consensus-based weight to any of the indicators used and to interpret the provisioning of ES not only from the viewpoint of economic gains or purely environmental protection, but from a much broader perspective. This includes sustained ability to yield a wide array of ES, which is important for the local population and Tatra National Park itself. We believe that this perspective is supported by the need to move away from area- and habitat-based assessment methods for both biodiversity and ecosystem services towards functional assessment at the landscape level, as highlighted by Tallis et al. (2015).

The set of indicators used in this study is based on published and available data dedicated to the ecosystem state before and after large-scale disturbances in the Tatra Mountains. As expected, not all the published data were temporally and spatially appropriate. A lot of data covered only a certain period (usually a short period after the disturbance), or focused only on limited disturbance type (e.g. fire), and therefore were excluded from the assessment.
The term 'impact' in the DPSIR framework usually implies negative environmental consequences of human activities. But there is substantial evidence that proactive management might successfully assist to sustain and maximise ES. Rounsevell et al. (2010) and Kelble et al. (2013) included ES directly into the DPSIR framework in lieu of impacts, thereby casting fresh light on how ecosystems function and produce ES, thus showing the capacity to provide more comprehensive information to decision-makers.

The response of the forest ecosystems in the Tatra Mountains to extensive disturbances exacerbated by climate and land-use changes has indicated a decline in ES provisioning. The biggest differences between the pre- and post-disturbance ecosystem capacity were recorded in the CES and RES in all disturbance and land-use categories.

It should be noted that ES also declined in the reference site. RES and CES declined in the first 5-yr period, whereas PES notably declined later. The decline of ES in the first 5 yr period resulted from individual tree dieback caused mostly by bark beetle. A steep decline in the second period was caused by the 2014 windthrow event. The ecosystem state and ES decline at the reference site are seen as consequences of synergies among the key driving forces (warmer climate, more frequent windstorms, impact of forest management and land-use changes) that affect the entire region of the Tatra Mountains.

The comparison of ES across the study sites showed that, as expected, the largest decline in the PES category was found in yield parameters. Ten years after disturbance, the CI values in all disturbed sites ranged from 0 to 0.11 , indicating a pronounced decline in ES. The same negative effect is associated with canopy fragmentation. The differences in PES among the sites were observed mainly in the amount of deadwood, the intensity of natural regeneration and the diversity of tree species. Deadwood in nonintervention sites (NEX, IPS) exceeded that in reference and intervention sites (REF, EXT) 3-fold. Similarly, the $\mathrm{CI}$ for natural regeneration was highest at the NEX site. In contrast to the EXT and FIR sites, the NEX site showed the lowest tree species diversity. Surprisingly, little differences among the sites were found in photosynthesis rate (GPP) even in the first $5 \mathrm{yr}$ after the windthrow disturbance (with the exception of the EXT site).

The decline in RES was the major concern when post-disturbance management strategies were discussed (Koreň 2015). Ten years after the windthrow disturbance, the wind-disturbed sites assimilated almost the same amount of carbon as the former 
mature forest. The NEX site assimilated even more carbon. The lowest assimilation rate was found at the IPS site. Fast recovery of the windthrow and fire sites was documented by a growing vegetation cover, expressed as LAI. The highest LAI was again found in the NEX site. IPS was the only site where LAI declined.

RES at the EXT and FIR sites $10 \mathrm{yr}$ after the windthrow disturbance almost reached the pre-disturbance level. REF and IPS sites featured continuation of the decline caused by the windthrow and bark beetle mainly due to the subsequent windthrow event. The amount of respired $\mathrm{CO}_{2}$ increased at all the study sites except at REF. It caused an obvious, large reduction in carbon sequestration. Except the NEX site, all the sites acted as carbon sources $10 \mathrm{yr}$ after disturbance. The largest decline $(\mathrm{CI}=0.04)$ was found at the IPS site. The CI at the salvage-logged sites (EXT, FIR) was influenced by change in natural composition and structure due to reforestation of the windthrow.

The energy balance (sensible heat) was found to be one of the most influential indicators for the overall CI of RES provision. The microclimate generated by fallen, unremoved wood at the NEX site reduced the heat impact 4 times more effectively than that at the reference site. Slight water erosion occurred during the first assessment period. The erosion was later eliminated by fast vegetation growth with the exception of the IPS site. The IPS site is located on steeper slopes and soil is more vulnerable to fine particle transport.

CES featured the lowest differences across the study sites. A relatively short distance between the study sites made it difficult to separate the number of visitors or their perception of attractiveness to distinct sites. The occurrence of allergens reduced CES most evidently $(\mathrm{CI}=0.25)$ at the EXT and FIR sites.

With regard to biodiversity, available data on, for example, soil fauna or ungulates population, indicated only small differences among either disturbance or management types. Generally, biodiversity increased in disturbed ecosystems, which supports the idea of a so-called 'disturbance paradox' (Thom \& Seidl 2016).

Significant and previously unknown changes occurred at the treeline. Forest ecosystems on the lee side of the Tatra Mountains are affected by significant disturbances caused by downslope winds in an approximately 60 yr cycle (Holeksa et al. 2016). Short periods between disturbances create conditions for the formation of fairly uniform forests, which are vulnerable to abiotic and biotic agents
(Zielonka et al. 2010, Fleischer \& Homolová 2011). Because the stands at the treeline are usually unaffected by this type of windstorm, late-stage succession forests were able to develop (Fleischer \& Koreň 2009). Most of the treeline forests are more natural and show much higher structural complexity than other mountain forests in the Tatra Mountains. Despite a severe climate and long-lasting air pollution impact (Bowman et al. 2008, Fleischer 2014), the treeline had remained stable for a long time. The situation has changed in the last decade due to enormous bark beetle pressure generated by increasing air temperature (Fleischer et al. 2016, Økland et al. 2016) and dramatic changes in landuse practices (introduction of non-intervention management on one-third of the Tatra National Park forest area). A further massive impact on the remaining forest at the treeline is expected in the following years. These findings support the predictions of Hlásny \& Turčáni (2013) and Hlásny et al. (2014) on the limited sustainability of Norway spruce forests in Central Europe associated with a climate change impact on spruce forest in the entire Carpathians.

Warm and wet summers have prevailed since 2004 and have probably facilitated the fast and successful recovery processes. Intense growth of young trees (positively interpreted from PES and RES due to carbon storage) was the reason for poor rooting and destruction of hundreds of hectares of $10 \mathrm{yr}$ old stands by the windstorm in 2014 (Pajtík et al. 2015). This event suggested that positive experience with forest regeneration and certain adaptation to disturbance does not necessarily imply continuation of the same patterns and dynamics under changing conditions (Vido 2015).

Climate change is expected to cause additional changes in the Tatra Mountains. Melo et al. (2013) classified the Tatra Mountains as the most climate change-threatened region in the Carpathians. According to bioclimatological ranges in the 'envelope' models (Kölling 2007), the projected climate would displace the current key species (Norway spruce and European larch) outside their natural growing conditions (Fleischer 2014).

Increasing tree species diversity by planting mixed forests is one of the forest management responses to eliminate the predicted consequences of climate change. In contrast, a higher vertical and spatial heterogeneity of natural tree regeneration, which results from biological processes, might eventually lead to a higher stability of stands without forestry intervention (Bače et al. 2015, Michalová 2015). 


\section{CONCLUSIONS}

The CES, PES and RES analysed in the study were below the pre-disturbance levels $10 \mathrm{yr}$ after the windthrow disturbance from 2004. It should be noted that the ecosystem also changed at the reference site as indicated by the decreased CI.

The analysis of 44 indicators of ES in the study area influenced by the disturbances, climate extremes and land-use changes showed:

- fast recovery at mountain foothills and postponed recovery at high-elevation slopes

- natural regeneration provided a limited number of tree species, while reforestation in managed sites increased diversity

- that fast and intensive regeneration occurred, especially at the non-intervention sites, which served as carbon sinks $10 \mathrm{yr}$ after the windthrow disturbance. However, the naturally dominant species Picea abies and Larix decidua are sensitive to climate change. In fact, this poses a risk for forest resilience under changing climate.

- no erosion or deviation from long-term hydrological conditions

- a high degree of variability in some indicators not only among the study sites, but also within them (soil moisture, soil respiration, carbon content, soil microorganisms, vegetation biomass, etc.) early after the disturbances. This spatial heterogeneity pattern supports forest resilience (Turner et al. 2013) and, together with fast and successful regeneration at disturbed sites, provides certain optimism with regard to the future uncertain conditions.

The analysis of indicators within the DPSIR framework proved useful for obtaining up-todate information on the ecosystem state needed by decisionmakers. This is especially important in the TANAP area, because despite the enormous public response, no consensus on its future management strategy has been achieved to date (Fleischer et al. 2016).

Further research and monitoring should focus on the role of high slope, elevation, geology and soil conditions in maintaining ecosystem state and services. From the analysed indicators, we can conclude that sustainable provision of ES in the area affected by repeated natural disturbances and threatened by climate change might be constrained. The managed sites require more resource input but support more resilient ecosystems (lower biomass, higher tree diversity). In contrast, unmanaged forests require only very limited resources, but they prove to be more vulnerable to natural disturbances and to anticipated climate change.
Acknowledgements. This article is based on work conducted under COST Action ES1203 SENSFOR, supported by COST (European Cooperation in Science and Technology, www. cost.eu/COST_Actions/essem/ES1203) and prepared with the support from the Slovak Grant Agency, grant numbers APVV-0480-12, APVV-0744-12, APVV-15-0425, APVV-140086, APVV-15-0176, APVV-15-0270, VEGA 1/0589/15, VEGA 1/0783/15 and VEGA 2/0055/15, and grant NPU I LO1415 funded by the Ministry of Education Youth and Sports of Czech Republic. We appreciate the comments of Jozef Turok and 2 anonymous reviewers that helped to improve the manuscript.

\section{LITERATURE CITED}

Bače R, Svoboda M, Janda P, Morrissey RC and others (2015) Legacy of pre-disturbance spatial pattern determines early structural diversity following severe disturbance in montane spruce forests. PLOS ONE 10: e0139214

Barredo JI, Bastrup-Kirk A, Teller A, Onaindia M and others (2015) Mapping and assessment of forest ecosystem and their services. Joint Research Centre, Ispra

* Bartík M, Sitko R, Ore ák M, Slovik J, Škvarenina J (2014) Snow accumulation and ablation in disturbed mountain spruce forest in West Tatra Mts. Biologia (Bratisl) 69: 1492-1501

Bičárová S, Fleischer P (2006) Windstorm effect on forest sources of biogenic volatile organic compound emissions in the High Tatras. Contrib Geophys Geod 36:269-282

Bičárová S, Holko L (2013) Changes of characteristics of daily precipitation and runoff in the High Tatra Mountains, Slovakia over the last fifty years. Contrib Geophys Geod 43:157-177

Bičárová $\mathrm{S}$, Bilčík D, Pavlendová $\mathrm{H}$, Janík R, Kellerová D (2015) Ground level ozone and windstorm. Stud Tan 11: 115-124 (in Slovak)

Bischoff WA, Mayer S, Schrumpf M, Freibauer A (2008) Nutrient leaching from soils affected by windfall in the High Tatras. In: Windstorm research 2008, State Forest of TANAP, Tatranská Lomnica, p 8-12

Bowman WD, Cleveland CC, Hakada L, Hreško J, Baron JS (2008) Negative impact of nitrogen deposition on soil bufferening capacity. Nat Geosci 1:767-770

Božíková J (2009) Climatic spas in Slovakia. In: Pribullová A, Bičárová S (eds) Sustainable development and bioclimate. Slovak Academy of Sciences, Stará Lesná, p 185-186

Brunette M, Holecy J, Sedliak M, Tucek J, Hanewinkel M (2015) An actuarial model of forest insurance against multiple natural hazards in fir (Abies Alba Mill.) stands in Slovakia. For Policy Econ 55:46-57

Bryce R, Irvine KN, Church A, Fish R, Ranger S, Kenter JO (2016) Subjective well-being indicators for large-scale assessment of cultural ecosystem services. Ecosyst Serv 21:258-269

Čekovská L (2013) Turism related problems in Tatranská Lomnica. PhD thesis, Comenius University, Bratislava

Dale VH (1997) The relationship between land-use change and climate change. Ecol Appl 7:753-769

*Don A, Bärwolff M, Kalbitz K, Andruschkewitsch R, Jungkunst HF (2012) No rapid soil carbon loss after a windthrow event in the High Tatra. For Ecol Manage 276: 239-246

Don A, Walter K, Bauer A (2015) Impact of the Tatra wind- 
throw on soil organic carbon stocks. Stud Tan 11:167-172

EEA (European Environment Agency) (2005) EEA core set of indicators: Guide. Tech rep No. 1/2005, EEA, Copenhagen

Fleischer P (2008) Windfall research and monitoring in the High Tatra Mts: objectives, principles, methods and current status. Contrib Geod Geophys 38:223-248

Fleischer P (2014) Impact of natural and antropogenic factors on state and changes in forest ecosystems in Tatra National Park. Hab thesis, Technical University in Zvolen

Fleischer P Jr (2016) Ecosystem exchange of $\mathrm{CO}_{2}$ in Norway spruce ecosystems after natural disturbances. $\mathrm{PhD}$ thesis, Technical University in Zvolen (in Slovak)

Fleischer P, Homolová Z (2011) Long-term ecological research in larch-spruce forest community after natural disturbances in the Tatra Mts. For J 57:237-250

Fleischer P, Koreň M (2009) Selected forest soil properties after the 2004 windfall in the Tatra Mts. In: Pribullová A, Bičarová S (eds) Sustainable development and dioclimate. Slovak Academy of Sciences, Stará Lesná, p 77-78

Fleischer P, Matejka F, St elcová K, Jakubjak O (2012) Meteorological and microclimate conditions on windthrow in the High Tatra Mts in 2012. In: Fleischer P (ed) 5th Windstorm Proc. State Forest of TANAP, Tatranská Lomnica, p 22-23

Fleischer P, Fleischer P Jr, Homolová Z (2015) Carbon balance of early succession vegetation on managed sites ten years after large-scale windthrow. Stud Tan 11:113-122

Fleischer P Jr, Fleischer P, Ferenčík J, Hlaváč P, Kozánek M (2016) Elevated bark temperature in unremoved stumps after disturbances facilitates multivoltinism in Ips typographus population in mountainous forest. Lesn Cas For $\mathrm{J}$ 62:15-22

Fleischer P, Hreško J, Topercer J (2017) What is the progress with zoning of TANAP? Environment 50:251-253 (in Slovak)

Frič M, Škvarenina J (2008) Microclimate influence on hydrochemical conditions of lysimetric waters in TANAP calamity area. In: Rožnovský J, Litschmann T (eds) Bioclimatological assessment of landscape processes. Czech bioclimatological society, Mikulov, p 1-12

Gardiner B, Blennow K, Carnus J, Fleischer P and others (2010) Destructive storms in European forests: past and forthcoming impacts. Final report to European Commission - DG Environ, European Forest Institute, Bordeaux, p 138

Gömöryová E, Střelcová K, Škvarenina J, Bebej J (2008) The impact of windthrow and fire disturbances on selected soil properties in the Tatra National Park. Soil Water Res 3:74-80

Gömöryová E, Střelcová K, Fleischer P, Gömöry D (2011) Soil microbial characteristics at the monitoring plots on windthrow areas of the Tatra National Park (Slovakia): their assessment as environmental indicators. Environ Monit Assess 174:31-45

Gömöryová E, Fleischer P, Pichler V, Homolák M, Gere R, Gömöry D (2017) Soil microorganisms at the windthrow plots: the effect of postdisturbance management and the time since disturbance. iForest 10:515-521

Grêt-Regamey A, Bebi P, Brunner SH, Weibel B (2015) On the importance of integrating expert knowledge into mapping ecosystem services: Swiss Alps forests. In Barredo et al. (eds) Mapping and assessment of forest ecosystems and their services. JRS science for policy report, European Commission, Ispra, p 18-23
Gubka A, Pavlík Š, Vakula J, Galko J (2010) Natural enemies of bark beetle after windfall in the Tatra Mts. In: Konôpka B (ed) Research on spruce stands destabilized by disturbances. National Forest Center, Zvolen, p 128-140

Hanajík P, Šimonovičová A (2015) Monitoring of soil characteristics on the calamity sites in TANAP (2005-2009). Stud Tan 11:145-155 (in Slovak)

Havašová M, Ferenčík J, Jakuš R (2017) Interactions between windthrow, bark beetles and forest management in the Tatra national parks. For Ecol Manage 391: 349-361

* Hlásny T, Turčáni M (2013) Persisting bark beetle outbreak indicates the unsustainability of secondary Norway spruce forest. Case study from Central Europe. Ann For Sci 70:481-491

Hlásny T, Nikolov C, Vakula J, Zúbrik M, Ferenčík J, Konôpka B (2010) Geostatistical analysis of Ips typographus population development after the 2004 windthrow in the High Tatra Mts. In: Konôpka B (ed) Research on spruce ecosystems destabilized by damaging factors. National Forest Center, Zvolen, p 86-95 (in Slovak)

Hlásny T, Mátyás C, Seidl R, Kulla L and others (2014) Climate change increases the drought risk in Central European forests: What are the options for adaptation? For J 60:5-18

Holeksa J, Zielonka T, Zywiec M, Fleischer P (2016) Identifying the disturbance history over a large area of larchspruce mountain forest in Central Europe. For Ecol Manage 361:318-327

Holko L, Škoda P (2016) Assessment of runoff changes in selected catchments of the High Tatra Mountains ten years after the windthrow. Acta Hydrologica Slovaca 17: 43-50 (in Slovak)

Holko L, Hlavatá H, Kostka Z, Novák J (2009) Hydrological regimes of small catchments in the High Tatra Mountains before and after extraordinary wind-induced deforestation. Folia Geographica XI:33-44

Holko L, Fleischer P, Novák V, Kostka Z, Bičárová S, Novák J (2012) Hydrological effects of a large scale windfall degradation in the High Tatra Mts, Slovakia. In: Křeček J, Haigh M, Hofer T, Kubin E (eds) Management of mountain watersheds. Springer, Dordrecht, p 164-179

Homolová Z, Kyselová Z, Šoltés R (2015) Vegetation changes on windthrow sites in larch-spruce forest community. Stud Tan 11:191-200 (in Slovak)

Jonášová M, Vávrová E, Cudlín P (2010) Western Carpathian mountain spruce forest after a windthrow: natural regeneration in cleared and uncleared areas. For Ecol Manage 259:1127-1134

Kajba M, Nikolov C, Ferenčík J, Gubka A (2013) Bark beetle calamity and the risk for tourists in the Tatra Mts. In: Kunca A (ed) Problems in forest protection, National Forest Center, Zvolen, p 121-124

Kelble CR, Loomis DK, Lovelace S, Nuttle WK and others (2013) The EBM-DPSIR conceptual model: integrating ecosystem services into the DPSIR framework. PLOS ONE 8:e70766

Kn̆ava K, Novák V, Orfánus T (2007) Canopy structure changes and potential evapotranspiration: possible influence of windthrow in High Tatra Mountains. In: Střelcová K, Matyas C, Kleidon A, Lapin M and others (eds) Bioclimatology and natural hazards. Slovak Bioclimatological Society, Zvolen, p 1-7

Kölling C (2007) Klimahüllen für 27 Waldbaumarten. AFZDerWald 23:1342-1345 
Kopecká M, Nováček J (2009) Forest fragmentation in the Tatra Region in the period 2000-2006. Landf Anal 10: 58-63

Koreň M (2015) TANAP's forest development in historical context. Stud Tan 11:59-74 (in Slovak)

Kyselová Z, Homolová Z (2012) Vegetation succession and cellulose decomposition in disturbed sites. In: Fleischer $P$ (ed) 5th Windstorm Proc, State Forest of TANAP, Tatranská Lomnica, p 41-42 (in Slovak)

Levin PS, Fogarty MJ, Matlock GC, Ernst M (2008) Integrated ecosystem assessment. NOAA Technical Memo, NMFSMWFSC-92

Máliš F, Fábry R, Vodálová A (2015) Vegetation development in spruce forest with different management after a windthrow. Stud Tan 11:199-209 (in Slovak)

Matejka F, Fleischer P (2011) Energetic balance of the windthrow area in Tatra Mts. Stud Tan 10:77-86 (in Slovak)

Maxim L, Spangenberg JH, O'Connor M (2009) An analysis of risk for biodiversity assessment under the DPSIR framework. Ecol Econ 69:12-23

Melo M, Lapin M, Kapolková H, Pecho J (2013) Climate trends in the Slovak part of the Carpathians. In: Kozak J, Ostapowicz K, Bytnerowicz A, Wyżga B (eds) The Carpathians: integrating nature and society towards sustainability. Springer, Berlin, p 131-150

Michalová Z (2015) Post-disturbance study on vegetation composition and natural regeneration in Tatra National Park. Stud Tan 11:211-220 (in Slovak)

Mišíková N, Škvarenina J (2009) Microclimatological condition on the burnt windfall area in the Tatra National Park. Meteorol J 12:31-36

Niemeijer D, de Groot RS (2008) Framing environmental indicators: moving from causal chains to causal networks. Environ Dev Sustain 10:89-106

Nikolov C, Konôpka B, Kajba M, Galko J, Kunca A, Janský L (2014) Post-disaster forest management and bark beetle outbreak in Tatra National Park, Slovakia. Mt Res Dev 34:326-335

Novák V, Kňava K (2009) Infiltration of water into stony soil: To what extent is inflitration affected by stoniness? In: Pribullová A. Bičárová S (eds) Sustainable development and bioclimate. Slovak Academy of Sciences, Stará Lesná, p 111-112

Novák V, Šurda P (2010) The water retention of a granite rock fragments in High Tatras stony soils. J Hydrol Hydromech 58:181-187

* Oesterwind D, Rau A, Zaiko A (2016) Drivers and pressures - untangling the terms commonly used in marine science and policy. J Environ Manage 181:8-15

Økland B, Nikolov C, Krokene P, Vakula J (2016) Transition from windfall-to patch-driven outbreak dynamics of the spruce bark beetle Ips typographus. For Ecol Manage 363:63-73

Pajtík J, Konôpka B, Šebeň V, Michelčík P, Fleischer P (2015) Biomass allocation of common larch in the first age class in the High Tatra Mts. Stud Tan 11:229-241 (in Slovak)

Pichler V (2015) Cooperation between Technical University in Zvolen and State Forest of TANAP in education for sustainable and adaptive forest management. Stud Tan 11:23-28 (in Slovak)

R Development Core Team (2008) R: a language and environment for statistical computing. R Foundation for Statistical Computing, Vienna

Rojan E (2015) Changes in unpaved forest roads of the wind- throw area in the Slovak High Tatra Mts in years 20042014. Stud Tan 11:85-94

* Rounsevell MDA, Dawson TD, Harrison PA (2010) A conceptual framework to assess the effects of environmental change on ecosystem services. Biodivers Conserv 19: 2823-2842

Kchelhaas MJ, Nabuurs GJ, Schuck A (2003) Natural disturbances in the European forests in the 19th and 20th centuries. Glob Change Biol 9:1620-1633

Schroeder LM, Lindelöw $\AA$ (2002) Attacks on living spruce trees by the bark beetle Ips typographus (Col. Scolytidae) following a storm-felling: a comparison between stands with and without removal of wind-felled trees. Agric For Entomol 4:47-56

Šebeň V, Bošela M, Kula L (2011a) Monitoring network for studying revitalisation of the windthrow in the Tatra Mts. Stud Tan 10:13-24 (in Slovak)

Šebeň V, Homolová Z, Fleischer P (2011b) Forest regeneration on the windfall research sites. Stud Tan 10:187-199y (in Slovak)

Seidl R, Schelhaas MJ, Lindner M, Lexer MJ (2009) Modelling bark beetle disturbances in a large scale forest scenario model to assess climate change impacts and evaluate adaptive management strategies. Reg Environ Change 9:101-119

Seidl R, Schelhaas M, Rammer W, Verkerk P (2014) Increasing forest disturbances in Europe and their impact on carbon storage. Nat Clim Change 4:806-810

Šimkovič I, Dlapa P, Šimonovičová A, Ziegler W (2009) Water repellency of mountain forest soils in relation to impact of the katabatic windstorm and subsequent management practices. Pol J Environ Stud 18:443-454

Sing L, Ray D, Watts K (2015) Ecosystem services and forest management. Research Note, Forestry Commission, Edinburgh

Sitko R, Midriak R, Fleischer P, Goceliak T, Pavlarčík S (2011) Water erosion after disturbances in the High Tatra Mts. Stud Tan 10:115-130 (in Slovak)

Smeets E, Weterings R (1999) Environmental indicators: typology and overview. Technical report No. 25, European Environment Agency, Copenhagen

Tallis H, Kennedy CM, Ruckelshaus M, Goldstein J, Kiesecker JM (2015) Mitigation for one and and all. An integrated framework for mitigation of development impacts on biodiversity and ecosystem services. Environ Impact Assess Rev 55:21-34

TEEB (The economics of ecosystems and biodiversity) (2010) Mainstreaming the economics of nature: a synthesis report of the approach, conclusions and recommenadations of TEEB, UNEP, Malta

Thom D, Seidl R (2016) Natural disturbance impacts on ecosystem services and biodiversity in temperate and boreal forests. Biol Rev Camb Philos Soc 91:760-781

* Turčeková L, Hurniková Z, Spišák F, Miterpáková M, Chovancová B (2014) Toxoplasmosa gondii in protected wildlife in the Tatra National Park, Slovakia. Ann Agri and Envi Medic 21:235-238

* Turner MG, Donato DC, Romme WH (2013) Consequences of spatial heterogeneity for ecosystem services in changing forest landscapes, priorities for future research. Landsc Ecol 28:1081-1097

Tutka J (2009) Enviromental and economic losses caussed by wind and bark beetle calamities. In: Kovalčík M (ed) Quantification of wind and bark beetle damage in TANAP. National Forest Center, Zvolen, p 145-148 
Vido J (2015) Drought periods in TANAP analyzed by SPI in 1961-2010. Stud Tan 11:95-101 (in Slovak)

Vyskot I, Schneider J, Kupec P, Fialová J, Melicharová A, Smítka D (2007) Wind calamity damages to sanitaryhygienic and social-recreational functions of forest in Tatra National Park. In: Rožnovský J, Litschmann T, Vyskot I (eds) Forest climate. Czech Bioclimatological Society, Křtiny, p 5

Wang Z, Zhou J, Loaiciga H, Guo H, Hong S (2015) A DPSIR model for ecological security assessment through indicator screening: a case study at Dianchi Lake in China. PLOS ONE 10:e0131732

Wermelinger B (2004) Ecology and management of the

Editorial responsibility: Nils Chr. Stenseth, Oslo, Norway spruce bark beetle Ips typographus - a review of recent research. For Ecol Manage 202:67-82

*Wolfslehner B, Vacik H (2008) Evaluating sustainable forest management strategies with the analytic network process in a pressure-state-response framework. J Environ Manage 88:1-10

Ziegler W (2007) Windthrow 2004 effects on carbon and nitrogen cycling. In: Fleischer P (ed) Windstorm research 2007. Stae Forest TANAP, Tatranska Lomnica

Zielonka T, Holeksa J, Fleischer P, Kapusta P (2010) A treering reconstruction of wind disturbances in a forest of the Slovakian Tatra Mountains, Western Carpathians. J Veg Sci 21:31-42

Submitted: April 8, 2016; Accepted: February 16, 2017

Proofs received from author(s): June 7, 2017 